원 저

$$
\begin{gathered}
\text { 결핵환자의 자연살해세포 매개 세포파괴능과 } \\
\text { 항체의존성 세포파괴능에 관한 연구( I ) }
\end{gathered}
$$

연세대학교 의과대학 내과학교실

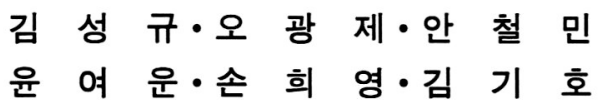

미 생 물 학 교 실

최 인 홍-윤 정 구

$=$ Abstract $=$

\title{
Natural Killer Cell Mediated Cytotoxicity and Antibody-Dependent Cell Mediated Cytotoxicity in Tuberculosis Patients ( I)
}

Sung Kyu Kim, M.D., Kwang Je Oh, M.D., Chul Min Ahn, M.D.

Yoe Wun Yoon, M.D., Hee Young Sohn M.D. and Ki Ho Kim, M.D.

Department of Internal Medinice, Yonsei University College of Medicine

In Hong Choi, M.D. and Jung Koo Yoon, M.D.

Department of Microbioloby

Cellular immunity is predominantly involved in pulmonary tuberculosis. Natural Killer (NK) cells and Killer (K) cells play an important role in cellular immunity.

Natural Killer cell mediated cytotoxicity (NKMC) was studied in 51 patients with active tuberculosis and 39 healthy controls. Antibodydependent cell mediated cytotoxicity(ADCC) was studied in 41 patients with active tuberculosis and 15 healthy controls.

There were no differences between the patients and the controls in NKMC and ADCC. There were no significant differences in the mean values of NKMC and ADCC among the minimal, moderately advanced and far advanced pulmonary tuberculosis patients.

We conclude that $\mathrm{NK}$ and $\mathrm{K}$ cells are not of prime importance in the body's defence against tuberculosis.

서 론

결핵은 우리나라의 대표적인 감염성 질환으로 항결핵 제 사용에도 불구하고 선진국보다 높은 유병율을 나타내 고 있다.

세포내 기생균인 결핵균(Mycoplasma tubeaulosis)

본 논문의 요지는 제 63 차 대한결핵 학회 추계 학술대회 (1986

년 11월 1일)석상에서 발표하였음
감염에 의한 만성질환은 그 치료 효과가 개인에 따라 차 이를 보이고 있으며 이는 약제내성 균주의 출현에 의한 결과뿐 아니라 환자의 면역 상태에 따라서도 질병의 정 도가 다르게 나타난다.

결핵은 세포성 면역 (cellular immunity)이 감소하는 질환으로 홍선의존 임파구(T-Lymphocyte), 대식세포 (macrophage), 용해성 매개물(soluble mediator)이 주로 관여하며, 최근에 자연살해세포(Natural Killer cell, NK cell)와 살해세포(killer cell, $\mathrm{K}$ cell)도 관여 
에 넣어 18 시간 $\mathrm{CO}_{2}$ 항습 항온기에 배양하면서 adherent cell은 제거한 후 사용하였다.

Target cell로는 murine L 1210 세포를 사용하였는데 이는 human NK 세포에 저항이 있는 것으로 알려져 있 다. 면역항체는 매주 $3-5 \times 10$ 의 C 1210 세포를 6 주간 $\mathrm{NZW}$ 토끼에 주사하여 얻었으며, 사용하기 전 $56^{\circ} \mathrm{C}$ 항 온수조에서 30 분 처리하여 비등화시켰다. 이 실험에서는 $1: 400$ 희석된 면역혈청을 사용하였다. 실험방법으로는
자연살해체포 매개 세포파괴능 측정과 동일한 $4 \mathrm{hr}-\mathrm{Cr}$ release technique을 사용하였으며, E : T ratio는 50 : 1 이었다. $\mathrm{ADCC}$ activity는 다음과 같은 공식으로 계산 하였다.

$\mathrm{ADCC} \%$ cytotoxicity $=\%$ cytotoxicity with serum- $\%$ cytotoxicity s serum.

Table 2. NK and ADCC Activity in Tuberculosis

\begin{tabular}{lcccc}
\hline \hline & \multicolumn{2}{c}{ NK } & & \multicolumn{2}{c}{ ADCC } \\
\cline { 2 - 5 } \cline { 5 - 5 } & $\mathrm{n}$ & $\%$ & $\mathrm{n}$ & $\%$ \\
\hline Health control & 39 & $38.70 \pm 18.64$ & 15 & $56.92 \pm 16.39$ \\
Tuberculosis & 51 & $37.64 \pm 18.64$ & 41 & $57.72 \pm 22.88$ \\
\hline Minimal active & 23 & $41.65 \pm 18.15$ & 18 & $58.30 \pm 22.53$ \\
Moderately advanced & 17 & $3633 \pm 19.37$ & 15 & $55.66 \pm 24.63$ \\
Far-advanced & 11 & $31.29 \pm 17.19$ & 8 & $60.28 \pm 22.99$ \\
\hline Cavitary & 14 & $33.33 \pm 14.99$ & 13 & $56.89 \pm 25.57$ \\
Non-cavitary & 37 & $39.22 \pm 19.51$ & 28 & $57.73 \pm 22.08$ \\
\hline
\end{tabular}

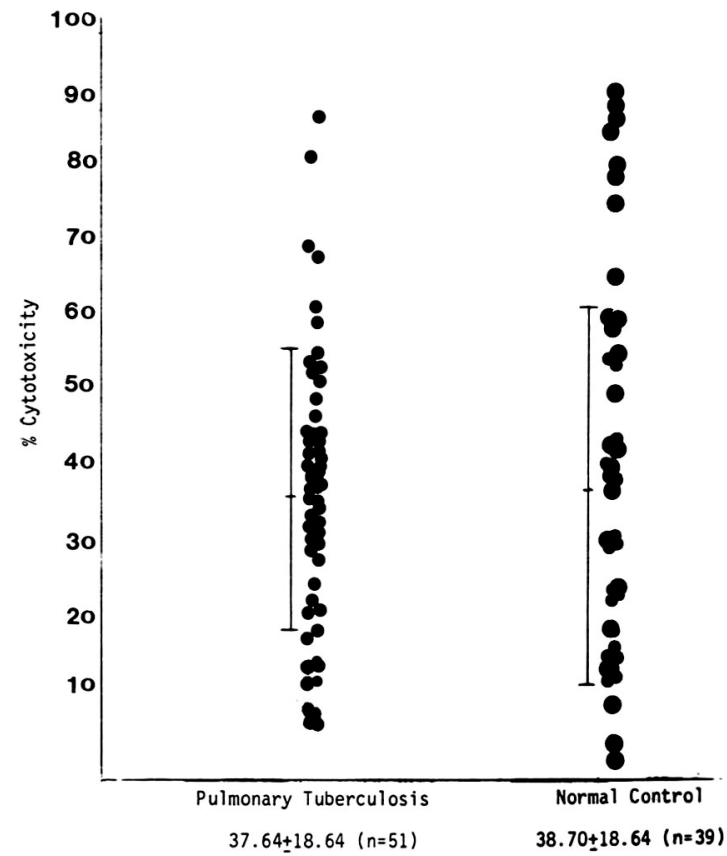

Fig. 1. NK activity in patients with pulmonary tuberculosis and normal control was not changed significantly.

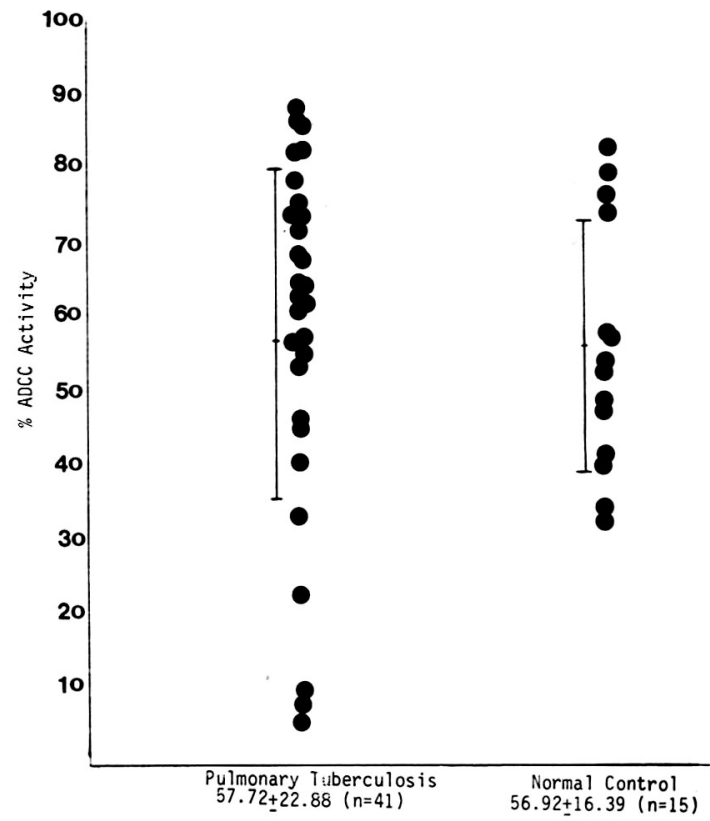

Fig. 2. ADCC activity in patients with pulmonary tuberculosis and normal control was not changed significantly. 
한다는 보고가 있었다 ${ }^{11}$.

외국에서는 이에대한 연구가 계속되어 왔지만 국내에 서는 문화식등히에 의해 결핵환자에서 자연살해세포 매 개 세포파괴능에 대한 보고가 있을뿐 항체의존성 세포파 괴능에 관한 보고는 없는 실정이다.

이에 저자들은 결핵환자의 자연살해세포 매개 세포파 괴 능(Natural killer cell mediated cytotoxicity)과 항체의존성 세포파괴능 (Antibody dependent cell mediated cytotoxicity, $\mathrm{ADCC}$ )을 함께 조사하여 몇 가지 성적을 얻었기에 일차 보고하는 바이다.

\section{실험대상 및 방법}

\section{1. 대 상}

1985년 5월부터 1986년 2월까지 연세대학교 의과대학 부속 세브란스병원에서 세균학적 검사방법에 의하여 활 동성 폐결핵으로 확진된 환자를 대상으로 하였다. 결핵 의 심한 정도에 따른 자연살해세포 파괴능의 차이가 있 는지를 보기위해 대상환자 51 명을 경증 23 명, 중등증 17 명, 중증 11 명으로 나누어 관찰하였으며 또한 공동의 유 무에 따른 차이가 있는지를 보기위해 대상 환자군을 공 동이 있는 14 명과 공동이 없는 37 명으로 나누어 관찰하 였는데 이때 정상인 39 명을 대조군으로 하여 비교해 보 았다.

또한 결핵의 심한정도에 따른 항체의존성 세포파괴능 차이가 있는지를 보기위해 대상환자 41 명을 경증 18 명, 중등증 15 명. 중증 8 명으로 나누어 관찰하였으며 공동의 유무에 따른 차이가 있는지를 보기위해 공동이 있는 13 명과 공동이 없는 28 명으로 나누어 관찰하였는데 이 때 정 상인 15 명을 대조군으로 하여 비교해 보았다(Table 1).

Table 1. Subjects

\begin{tabular}{lcc}
\hline \hline & \multicolumn{2}{c}{ Number of cases } \\
\cline { 2 - 3 } & NK activity & K activity \\
\hline Tuberculosis & 51 & 41 \\
Minimal active & 23 & 18 \\
Moderately advanced & 17 & 15 \\
Far-advanced & 11 & 8 \\
\hline Health control & 39 & 15 \\
\hline
\end{tabular}

\section{2. 실헙방법}

1) 말초헐액 임파구 분리

본 실험예 사용한 환자의 말초혈액은 모든 치료전에 채 취하였다. Heparin 처리 말초쳘액은 penicillin(100 단 위 $/ \mathrm{ml})$ 과 streptomycin $(100 / / \mathrm{g} / \mathrm{ml})$ 이 첨가된 $\mathrm{RPMI}$ 1640 배지 (M.A. Bioproducts. U.S.A.) 로 1: 1 혼합 희 석후 Ficoll-Hypaque 용액 $(1.077 \mathrm{~g} / \mathrm{ml}$ density) 을 사용 한 비중변화도 원심법(density gradient centrifugation)에 따라 림프구를 분리하였다.

\section{2) 자연살해세포 매개 세포파괴능}

자연살해세포 매개 세포독성을 측정하기 위하여 말초 혈액 림프구를 $10 \mathrm{mM}$ HEPES $1.6 \mathrm{mM}$ L-glutamine, $100 \mathrm{IU}$ penicillin, $100 \mu \mathrm{g}$ streptomycin 및 $10 \%$ fetal calf serum이 포함된 RPMI 1640 배지에 희석하여, plastic petri dish에 넣어 18 시간, $\mathrm{CO}_{2}$ 항습 항온기에 배 양하면서 adherent cell은 제거한 후 사용하였다.

자연살해세포 매개 세 포독성은 target cell인 K-562 세 포를 이용하여 $\mathrm{Cr}$ 방출방법을 이용하였다. 즉 target cell 인 K-562 세포 10세포/0.2 ml를 $100 \mathrm{mCi} \mathrm{Na}_{2} \mathrm{CrO}_{4}$ (1 $\mathrm{mCi} / \mathrm{ml} \mathrm{NEZ}-0.305$, New England Nuclear, Boston, Mass U.S.A.) 와 $37^{\circ} \mathrm{C}$ 진탕 항온조에서 1시간 lable시켰 다. 그후 3 회 세척후 $51 \mathrm{Cr}$ 이 lable된 세포를 microplate 각 Well당 10세포되게 넣고 effector: target 세포의 비 율을 (E:T ratio) $50: 1$ 되게 넣어 $37^{\circ} \mathrm{C}, 5 \% \mathrm{CO}_{2}$ 항습 항 온기에서 4 시간 배양하였다.

이 때 maximal release를 유발시키기 위해서 $0.25 \%$ Triton X-100 (sigma chemical Co, U.S.A.)를 사용하 였고, spontaneous release를 측정하기 위해서는 $\mathrm{Cr}$ lable된 target cell만 배양하였다.

배양후 $50 \mu 1$ 의 상층액을 수거하여 gamma counter로 radioactivity를 측정하고, 자연살해세포 매개, 세포독성 1 은 다음 공식에 의하여 계산하였다.

$\%$ cytotoxicity $=$ $\frac{\text { test release }- \text { spontaneous release }}{\text { maximum release--spontaneous release }}$

3) 항체의존성 세포파괴능

항체의존성 세포파리능을 측정하기 위하여 말초혈액 림프구를 $10 \mathrm{mM} \mathrm{HEPES} \mathrm{및} \mathrm{10 \%} \mathrm{fetal} \mathrm{calf} \mathrm{serum이}$ 포함된 RPMI 1640 배지에 희석하여, plastic petri dish 


\section{실 험 성 적}

1) 정상인의 평균 자연살해세포 매개 세포파괴능은

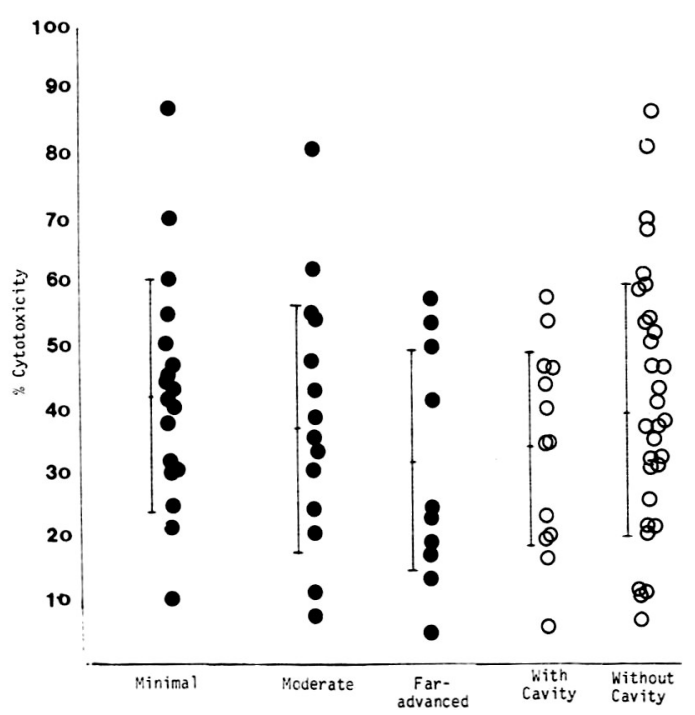

Fig. 3. Among the groups of patients with minimal, moderate, or far-advanced tuberculosis, whether with or without cavity, there were no significant differences in NK activity.

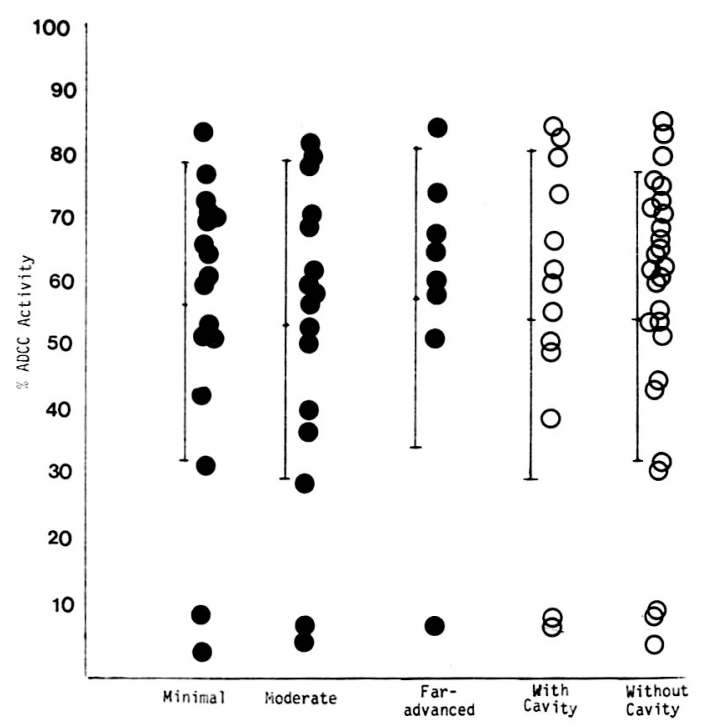

Fig. 4. Among the groups of patients with minimal, moderate, or far-advanced tuberculosis, where with or without cavity, there were no significant differences in ADCC activity.
$38.70 \pm 18.64 \%$ 였으며 항체 의존성 세포파괴능은 $56.92 \pm 16.39 \%$ 였다 (Table 2).

2) 폐 결핵환자의 자연살해세포 매개 세포파괴능은 $37.64 \pm 18.64 \%$, 항체 의존성 세포파괴능은 $57.72 \pm$ $22.88 \%$ 였다(Table 2 ).

3) 정상대조군과 폐 결핵환자의 자연살해세포 매개 세 포파괴능과 항체 의존성 세포파괴능에는 유의한 차이가 없었다(Fig. 1, 2).

4) 경증, 중등증 및 중증환자군의 평균 자연살해세포 매개 세포파괴능은 $41.65 \pm 18.15,36.33 \pm 1.37,31.29 \pm$ $17.19 \%$ 로 중증일수록 감소하는 양상을 보였으나 통계학 적으로 유의는 없었다(Fig. 3).

5) 공동이 있는 환자와 없는 환자의 자연살해세포 매 개 세포파괴능은 $33.33 \pm 14.99,39.22 \pm 19.51 \%$ 로 공동 의 유무에 따른 자연살해세포 매개 세포파괴능의 유의한 차이는 없었다(Fig. 3).

6) 경증, 중등증 및 중증환자군의 평균 항체 의존성 세 포파괴능은 각각 $58.30 \pm 22.53,55.66 \pm 24.63,60.28 \pm$ $22.99 \%$ 로 결핵정도의 경중간에는 유의한 차이가 없었다 (Fig. 4).

7) 공동이 있는 환자의 항체 의존성 세포파괴능과 공 동이 없는 환자의 항체의존성 세포파괴능은 $56.89 \pm 25$. $57 \%, 57.73 \pm 22.08 \%$ 로 공동의 유무에 따른 통계학적 유의는 없었다(Fig. 4).

\section{고 찰}

결핵은 세포성 면역반응이 관여하는 대표적 질환으로 알려져 있으며, 특정항원에 감작된 임파구가 동일 항원 에 의해 자극을 받으면 용해성 매개물 (soluble mediator)을 분비하고 이 매개물이 대식세포를 활성화시켜 결 핵균의 번식을 막는 것으로 되어있다.

세포성 면역에 관여하는 세포는 단핵구, 대식구 (macrophage), 홍선의존 임 파구(T-lymphocyte) 가 주 된 세포들이며 살해세포(Killer cell)와 자연살해세포 (Natural killer cell) 도 면역작용에 관여한다고 되어 있 으나 결핵균의 증식을 억제하는 것으로는 활성화된 대식 구(activated macrophage) 가 중요한 역할을 담당하는 것으로 되어있다 ${ }^{3,4)}$.

자연살해세포와 살해세포는 면역 글로불린의 $\mathrm{Fc}$ 에 대 한 수용체를 갖고 있으며 숙주 방어기전에서 중요한 역 
할을 담당하여 이미 종양면역이나 숙주면역감시능 및 이 식편에 대한 거부반응에 많은 연구가 되어 있다 ${ }^{5,6)}$.

살해세포와 자연살해세포는 "Null cell”로 알려져 왔 으며 살해세포는 단핵구一대식구 계열로 항체와 반응하 여 표적세포를 파괴하여 항체 의존성 세포독성 $(\mathrm{ADCC})$ 로 불리어 진다. 살해세포의 $\mathrm{Fc}$ 수용체를 통해 항체와 결합 하여 표적세포를 파괴하며 이 반응은 특수한(specific) 한 것으로 되어 있다.

자연 살해세포는 비장이나 임파선 말초혈 액에서 발견되 며 큰 과립성 (large granular) 세 포이며, 말초혈액의 $5 \%$ 정도 차지하고 있다. 이 세포는 풍부한 세포질과 핵을 함 유하며 T cell의 특징인 세포표면에 Ly-5, Thy-1를 갖 고 있으나 Thy-1, 2, 3은 갖고 있지 않다.

또 자연살해세포는 살해세포와 달리 세포파괴능을 나 타내는데 항체가 필요하지 않으며 비특이성 (non-specific)인 것이 특징이다.

특히 자연살해세포는 성유아세포(fibroblast), 훙선의 존임파구(thymocyte) 등도 파괴하지만 정상적인 세포보 다도 임파종양이나 어떤 종양세포글를 더 잘 파괴하는 것 으로 되어있다. 자연 살해세포는 항원에 대한 감작없이 표 적세포를 파괴하며 $\mathrm{lL}-2$ 나 interferon, poly A, poly U 에 의해서 파괴능이 증가된다. 또 virus ${ }^{8)}$ 나 다른 미생 물 ${ }^{9)}$ 에 의한 질환에 있어서 자연방어기전에 관여한다고 알려 져 있다.

위와같이 병원균에 의한 자연방어기전에 관여하는 자 연살해세포나 살해세포와 세포성면역의 일종인 결핵 과의 관계를 알고자 저자등은 K-562 세포와 L 1210 세포를 표 적세포로하여 활동성 결핵환자의 자연살해세포 매개 세 포독성과 항체의존성 세포독성을 실험측정하였다.

저자등은 활동성 결핵환자의 자연살해세포 매개 세포 독성과 항체의존성 세포독성은 대조군과 유의한 차이가 없었고 경증, 중등증, 중증 폐결핵환자군 상호간의 유의 한 차가 관찰되지 않았다.

현재까지 폐결핵환자의 $\mathrm{NKMC}$ 나 $\mathrm{ADCC}$ 에 관하여 여 러가지 보고가 있으나 onwubalili등미은 폐결핵과 자연 살해세포 매개 세포독성이 관계가 없는 것으로 보고하고 있으나 Ylna 등그는 폐결핵환자에서 활동성 대식구가 interferon 등을 분비하여 자연 살해세포나 살해세포독성 을 중가시킨다고 보고하고 있다.

한편 문화식 ${ }^{2)}, \operatorname{Roder}^{11)}$, Tracey 등 ${ }^{12)}$ 은 폐결핵환자 에 있어서 자연살해세포 매개 세포독성이 대조군에 비해
감소되었다고 보고 하였지만 저자들은 본 실험을 통해 활 동성 폐결핵환자에서 자연살해세포 매개 세포독성과 항 체의존성 세포독성이 대조군에 비해 유의한 차이를 볼 수 가 없었다. 그러나 폐결핵을 치료하는 과정에서의 자연 살해세포 매개 세포독성과 항체 의존성 세포독성의 변화 와 항결핵제가 자연살해세포 매개 세포독성과 항체의존 성 세포독성에 어떠한 영향을 미치는가를 계속 관찰중이 며 추후 종합하여 보고자 한다.

\section{결 론}

결핵환자의 자연살해세포 및 살해세포의 역할을 알아 보기위해 활동성 폐결핵환자군(경증 23 명, 중등증 17 명, 중증 23 명 ; 공동이 있는 환자 14 명, 공동이 없는 환자 37 명)과 정상대조군 (39명)을 대상으로 자연살해세포 매개 세포독성을 측정하였으며 활동성 폐결핵환자군(경증 18 명, 중등증 15 명, 중증 8 명 ; 공동이 있는 환자 13 명, 공 동이 없는 환자 28명) 과 정상 대조군 (15명)을 대상으로 항체의존성 세포독성을 측정하여 다음과 같은 결론을 얻 었다.

1) 결핵 환자군과 정상대조군과의 $\mathrm{NKMC}$ 에 유의한 차이가 없었다.

2) 결핵 환자군과 정상대조군과의 $\mathrm{ADCC}$ 에는 유의한 차이가 없었다.

3) 결핵의 경중에 따른 환자군간의 NKMC 및 공동의 유무에 따른 $\mathrm{NKMC}$ 에는 유의한 차이가 없었다.

4) 결핵의 경중에 따른 환자군간의 $\mathrm{ADCC}$ 및 공동의 유무에 따른 $\mathrm{ADCC}$ 에는 유의한 차이가 없었다.

\section{REFERENCES}

1) YIna, M Yamamoto: Killer and natural killer activities in pulmonary tuberculosis. Bulletin of the internal union against Tuberculosis 58:3, 1983

2) 문화식, 김훈교, 김호연, 박성학, 김춘추, 김동집, 변 해원 : 결핵환자의 자연살해세포 매개 세포 파괴능. 결 핵 및 호홉기질한 28:151, 1981

3) Youmans GP: Mechanisms of immunity in tuberculosis. Pathobiol Annu 9:137, 1979

4) Walker L, Lowrie DB: Killing of mycobacterium microti by immunologically activated macrophages. Nature 193:69, 1981

5) Lopez C, Kirkpatrick D, Sorell M, O'Reilly RJ, 
Ching C: Association between pretransplant natural killer and graft-versus-host disease after stem-cell transplantation. Lancet 1103, 1979

6) 김동집, 김춘추, 한치화, 박종원, 김훈교, 김효연, 김 원일, 이연태 : 암환자의 세포성 면역. II. 자연살해세 포 매개 세포 파괴능의 변동. 대한내과학회잡지 24:461, 1981

7) Hanna N, Burton RC: Definitive evidence that natural killer $(\mathrm{NK})$ cells inhibit experimental tumour metastasis in vivo. J Immunol 127:1754, 1981

8) Ching C, Lopez C: Natural killing of herpes simplex virus type 1-infected target cells: normal human responses and influence of antiviral antibody. Infect
Immun 26:49, 1979

9) Roder JG, Pross HF: The biology of the human natural killer cell. J Clin Immunol 2:249, 1982

10) Onwubalili JK, Scott GM: Natural killer cell activity in tuberculosis. Br J Dis Chest 67:79, 1985

11) Roder JC, Klein M: Target-effector interaction in the natural killer cell system. IV. Modulation by cyclic nucleotides. J Immunol 123:2785, 1979

12) Tracey DE, Adkinson NF: Prostaglandin synthesis inhibitors potentiate the BCG-induced augmentation of natural killer cell activity. J immunol 125: 136, 1980 